\title{
Complex Communication Needs of a Child with Dandy-Walker Syndrome and Mucopolysaccharidosis Type II Case Study
}

\author{
Złożone potrzeby komunikacyjne dziecka ze zdiagnozowanym \\ zespołem Dandy-Walkera i mukopolisacharydozą \\ typu II. Studium przypadku
}

Keywords: complex communication needs, rare disease, Dandy-Walker syndrome, mucopolysaccharidosis type II

Słowa kluczowe: złożone potrzeby komunikacyjne, choroba rzadka, zespół Dandy-Walkera, mukopolisacharydoza typu II

\begin{abstract}
There exist few publications describing the cases of children diagnosed with two rare diseases. Most of them are medical case studies. The purpose of the research was to describe the complex communication needs of a child and the resulting needs in the area of me as a person and in the home, social, educational, therapeutic and medical environment.

The research involved a boy in early school age diagnosed with the Dandy-Walker syndrome and mucopolysaccharidosis type II (Hunter syndrome). The research was embedded in qualitative orientation using an individual case study. The research was conducted over a period of four years (2016 to 2020).

The complex communication needs diagnosed in the boy triggered the following needs in the area of "me as a person": to notice the effects of one's actions, to have a sense of being a member of a group, to engage in activities that will help develop one's own competencies and gain experience, and to be included in group activities. The research suggests that all of the above

\footnotetext{
* Uniwersytet Kazimierza Wielkiego w Bydgoszczy, Wydział Pedagogiki, Katedra Pedagogiki Specjalnej i Logopedii, ul. Powstańców Wlkp. 2, 85-090 Bydgoszcz, e-mail: a.kamwaw@ukw.edu.pl, ORCID: https://orcid.org/0000-0002-0545-6416.
} 
mentioned needs exist in the home and social environment area. In terms of education, it was determined that there is no need for a teaching assistant/aide who would know alternative methods of communication and could adapt the classroom to multimodal communication and train other persons. In terms of therapy, there was no need to create a controlled space in an institution, as therapy, the same as education, takes place in the boy's home. In terms of medical care, Adam has all the above mentioned needs.

\section{Streszczenie}

Publikacje opisujące przypadki dzieci ze zdiagnozowanymi dwiema chorobami rzadkimi są nieliczne. Najczęściej są to medyczne prace kazuistyczne. Celem badań przedstawionych w niniejszym artykule jest opisanie złożonych potrzeb komunikacyjnych dziecka i wynikających z nich potrzeb w obszarze ,ja jako osoba”, w środowisku domowym, społecznym, edukacyjnym, terapeutycznym i medycznym.

Badaniami objęto chłopca w młodszym wieku szkolnym ze zdiagnozowanym zespołem Dandy-Walkera i mukopolisacharydozą typu II (zespołem Huntera). Badania osadzono w orientacji jakościowej z wykorzystaniem indywidualnego studium przypadku. Były one prowadzone przez cztery lata (2016-2020).

Zdiagnozowanie u chłopca złożonych potrzeb komunikacyjnych przyczyniło się do zaistnienia w obszarze „ja jako osoba” następujących potrzeb: dostrzegania skutków swojego działania, poczucia bycia członkiem grupy, aktywności, która przyczyni się do budowania własnych kompetencji i zdobywania doświadczenia oraz włączania w aktywności grupowe. W obszarze „środowisko domowe i społeczne” na podstawie przeprowadzonych badań można wskazać, że zaistniały wszystkie wskazane potrzeby. W zakresie edukacji nie pojawiła się potrzeba zapewnienia nauczyciela wspomagającego/asystenta znającego alternatywne metody komunikacji, który dostosuje pomieszczenie do nauki pod kątem komunikacji wielomodalnej oraz przeszkoli inne osoby. Jeżeli chodzi o terapię, to nie zaistniała potrzeba stworzenia kontrolowanej przestrzeni w placówce, ponieważ - tak jak w przypadku edukacji - odbywa się ona także w domu chłopca. W zakresie opieki medycznej badane dziecko wykazuje wszystkie wskazane potrzeby.

\section{Introduction}

The medical, educational and speech therapy literature describes a very limited number of cases of children enrolled in early grades who have been diagnosed with two rare diseases. The few existing publications focus on the medical aspect of the functioning of persons with such a rare diagnosis. There are no research papers related to speech and communication or cognitive functioning, and this is due to several reasons. First of all, two rare diseases are very seldom diagnosed, and sometimes they are even unique. Secondly, children with such diagnosis usually die shortly after birth, or before they turn five [Schieppati et al., 2008; Richter et al., 2015]. Thirdly, 
once parents are informed by a geneticist about their child's condition, they are usually not pursue medical examination any further. They are often told that the symptoms they notice in their son or daughter are a coexisting disorder rather than a separate syndrome.

\section{Complex communication needs of a child with developmental problems - a literature review}

There are many definitions of complex communication needs (CCN). The term was proposed by the International Society for Augmentative and Alternative Communication to replace two former names: severe communication disorders and severe communication impairments [Grycman, 2014]. Persons with CNN may lack communication skills to meet all their needs and their situation may be temporary or permanent. They are persons who: a) do not speak, but instead use different methods of communication (e.g. gestures, pointing); b) can speak, but find it difficult to understand the speech of other persons or, c) can speak but their speech is hard to understand for others [Department of Communities, Disability Services and Seniors, 2018]. Pickl notes that if a child with developmental difficulties has complex communication needs, it means that their speech is either too limited or non-existent, which makes it impossible for the child to express their needs or desires, or share information with others [Pickl, 2008]. Grycman adds that CCN limits or prevents fulfilment of life or social functions and that such difficulties may exist in all forms of communication, in any environment and with all kinds of communication partners [Grycman, 2014]. Meanwhile, Sigafoos and Gevarter claim that such significant difficulties with using speech require support and targeted intervention. In their opinion, complex communication needs are:

\footnotetext{
[...] situations where a person lacks sufficient speech and language to engage in everyday communicative interactions. People with complex communication needs have considerable difficulty with the production of speech, the understanding of speech and language, and the use of reading and writing skills. The term is generally reserved for cases in which speech and language impairment is significantly impaired; not merely delayed. This term is also not applied to the Deaf, who most often learn to communicate effectively through sign language. Rather, individuals with complex communication needs display a degree of communication impairment that is severe, pervasive, and unlikely to be resolved to any appreciable degree without deliberate, explicit, and often intensive intervention efforts [Sigafoos, Gevarter, 2019, p. 768].
}

Other definitions - including the one recommended by the Australian Parliament of Victoria Family and Community Development Committee emphasise the 
fact that $\mathrm{CCN}$ is a broad concept which, as previously mentioned, concerns difficulties with communicating through speech and writing and with understanding the communication of other persons. Furthermore, they state that those difficulties may be associated with a developmental disability such as, for example, various degrees of intellectual disabilities, autism spectrum disorders or disabilities acquired due to brain damage or stroke [Parliament of Victoria Family and Community Development Committee, 2016].

Based on a literature analysis, it may be noted that all the definitions of complex communication needs stress:

- limited or lack of speech;

- difficulties with or inability to express one's needs and thoughts;

- limited ability to perform life and social roles;

- may affect both children and adults diagnosed with intellectual disabilities or suffering from intellectual disability as a result of another disorder;

- the need to provide support and intervention efforts to persons diagnosed with CCN.

Given the specificity of the functioning of children with a rare disease that is often degenerative and involves, among other things, gradual loss of speech skills, the CCN definition proposed by Sigafoos and Gevarter was used in conducting this research. Complex communication, will be a concern for children diagnosed with $\mathrm{CNN}$, and intellectual disability and other acquired disabilities will limit or prevent their ability to use speech in a way that is understandable to others and to understand the speech of others [McNaughton et al., 2012]. It should be noted that those needs will also be a concern for children with a rare disease such as, for example, mucopolysaccharidosis type II or Dandy-Walker syndrome.

Based on an analysis of the current research literature concerning on the functioning of children with $\mathrm{CNN}$, it is possible to identify the areas of life affected by this diagnosis. They include, among other things, "me as a person", the home environment, the social environment, education, therapy, or medical care (Table 1). The identification of those areas, allow to delineate specific needs for children who have this diagnosis so they may fully participate both in family and in social life. 
Table 1. The areas of a child's life whose quality determines the existence of complex communication needs

\begin{tabular}{|c|c|c|c|}
\hline Area & Possible functioning & Selected needs & $\begin{array}{l}\text { Common need for all } \\
\text { areas }\end{array}$ \\
\hline $\begin{array}{l}\text { Me as } \\
\text { a person }\end{array}$ & \begin{tabular}{|l} 
- Obstacles \\
in communicating basic \\
needs, sharing ones' own \\
experiences and the \\
associated emotions \\
- A sense of not being \\
understood \\
- Frustration \\
- Under-evaluation \\
of one's own \\
competencies \\
and values \\
- Lack of self- \\
determination \\
- Problems with \\
establishing \\
relationships \\
- Experiencing barriers: \\
- a) Limitations in current \\
possibilities of an \\
individual or in the \\
communication system \\
that a child uses \\
- b) Associated with \\
opportunities \\
(limitations arising \\
from policies, practice, \\
knowledge/skills \\
of professionals \\
or communication \\
partners and attitudes) \\
\end{tabular} & $\begin{array}{l}\text { - To notice the effects } \\
\text { of one's own actions } \\
\text { - To have a sense of being } \\
\text { a member of a group } \\
\text { - To engage in an activity } \\
\text { that will help develop } \\
\text { one's competencies and } \\
\text { gain experience } \\
\text { - To be included in group } \\
\text { activities }\end{array}$ & \multirow[t]{2}{*}{$\begin{array}{l}\text { - To create } \\
\text { a communication code } \\
\text { with a child (to associate } \\
\text { a pre-identified } \\
\text { behaviour with } \\
\text { unambiguous meaning) } \\
\text { - To adapt the } \\
\text { environment to an } \\
\text { AAC user } \\
\text { - To have access } \\
\text { to a broad range of ICT } \\
\text { tools and social media } \\
\text { that are important for } \\
\text { teenagers and may } \\
\text { constitute a basis for } \\
\text { both education and } \\
\text { therapy (exchange } \\
\text { of information, pictures, } \\
\text { films, etc.) } \\
\text { - To create a support } \\
\text { group }\end{array}$} \\
\hline $\begin{array}{l}\text { Home } \\
\text { environment }\end{array}$ & \begin{tabular}{|l|} 
- Limited ability \\
to participate in wider \\
family gatherings with \\
relatives that do not \\
have regular contacts \\
with the child \\
- Isolation from the local \\
community and external \\
environment may lead \\
to mistreatment and \\
emotional and physical \\
abuse
\end{tabular} & $\begin{array}{l}\text { - Familiarising family } \\
\text { members and relatives } \\
\text { with the means } \\
\text { of communication } \\
\text { - Separation from one } \\
\text { of the parents who } \\
\text { has assumed the role } \\
\text { of interpreter } \\
\text { - Acting as a son, brother, } \\
\text { cousin }\end{array}$ & \\
\hline
\end{tabular}


Tabela 1. (continued)

\begin{tabular}{|c|c|c|c|}
\hline Area & Possible functioning & Selected needs & $\begin{array}{l}\text { Common need for all } \\
\text { areas }\end{array}$ \\
\hline $\begin{array}{l}\text { Social } \\
\text { environment }\end{array}$ & $\begin{array}{l}\text { - Social discrimination } \\
\text { - The role of a passive } \\
\text { observer } \\
\text { - Exclusion } \\
\text { - The need to be } \\
\text { accompanied by a carer } \\
\text { who acts as an } \\
\text { interpreter }\end{array}$ & $\begin{array}{l}\text { - To improve the } \\
\text { understanding } \\
\text { of communicated } \\
\text { information } \\
\text { - To have access } \\
\text { to tools that facilitate } \\
\text { communication and are } \\
\text { available in public space } \\
\text { - To observe the } \\
\text { principles of universal } \\
\text { design of urban space, } \\
\text { taking into account, } \\
\text { among other things, the } \\
\text { principle of multimodal } \\
\text { communication }\end{array}$ & \\
\hline Education & $\begin{array}{l}\text { - Lack of self- } \\
\text { determination } \\
\text { - Problems with } \\
\text { establishing } \\
\text { relationships } \\
\text { - Limitations caused } \\
\text { by systematic solutions } \\
\text { - Common patterns } \\
\text { of communication not } \\
\text { adequate to the child's } \\
\text { CCN }\end{array}$ & $\begin{array}{l}\text { - To ensure the child's } \\
\text { proper position } \\
\text { in the process } \\
\text { of communication } \\
\text { - To ensure the presence } \\
\text { of a teaching assistant/ } \\
\text { aide who would know } \\
\text { alternative methods } \\
\text { of communication } \\
\text { and could adapt the } \\
\text { classroom to multimodal } \\
\text { communication and } \\
\text { train other persons } \\
\text { - To customise the } \\
\text { teaching strategy } \\
\text { by means of, among } \\
\text { other things, the } \\
\text { technological tools that } \\
\text { facilitate communication }\end{array}$ & \\
\hline Therapy & $\begin{array}{l}\text { - Lack of self- } \\
\text { determination } \\
\text { - Problems with } \\
\text { establishing } \\
\text { relationships } \\
\text { - Inability to communicate } \\
\text { one's feelings and } \\
\text { emotions (joy, anger, } \\
\text { dissatisfaction with } \\
\text { activities) }\end{array}$ & $\begin{array}{l}\text { - To create controlled } \\
\text { space in an institution } \\
\text { - To select therapy } \\
\text { methods that would } \\
\text { enable using alternative } \\
\text { communication tools }\end{array}$ & \\
\hline
\end{tabular}




\begin{tabular}{|c|c|c|c|}
\hline Area & Possible functioning & Selected needs & $\begin{array}{c}\text { Common need for all } \\
\text { areas }\end{array}$ \\
\hline Medical care & $\begin{array}{l}\text { - Lack of self- } \\
\text { determination } \\
\text { - The need to be } \\
\text { accompanied by a carer } \\
\text { acting as an interpreter } \\
\text { during medical } \\
\text { appointments } \\
\text { - Lack of intimacy } \\
\text { due to the need } \\
\text { to be accompanied } \\
\text { by a person who will } \\
\text { help communicate with } \\
\text { the doctor } \\
\text { - Problems with } \\
\text { establishing } \\
\text { relationships } \\
\text { - Not fitting into the } \\
\text { existing system of care } \\
\text { and support }\end{array}$ & $\begin{array}{l}\text { - To participate } \\
\text { in rehabilitation } \\
\text { programmes for children } \\
\text { using AAC } \\
\text { - To observe the principles } \\
\text { of universal design } \\
\text { of medical facilities, } \\
\text { taking into account, } \\
\text { among other things, the } \\
\text { principle of multimodal } \\
\text { communication } \\
\text { - To have access to tools } \\
\text { that would enable } \\
\text { communication with } \\
\text { the medical personnel } \\
\text { without the assistance } \\
\text { of an interpreter }\end{array}$ & \\
\hline
\end{tabular}

Source: McNaughton et al., 2012; Grycman, 2014; Hourcade et al., 2014; Johnston et al., 2020.

\section{Mucopolysaccharidosis type II and Dandy-Walker syndrome as examples of rare diseases diagnosed in children}

Definitions of rare diseases may differ between countries. In general, a rare disease is one that affects a limited number of individuals, making it difficult for those individuals to be diagnosed and receive specialized treatment. Most of such diseases are diagnosed in children and 30\% of such children die before they reach the age of five years [Schieppati et al., 2008; Richter et al., 2015]. There are different data on the number of individuals with such diagnosis because a certain disease may be more common in some countries than in others. However, it in the European Union a rare disease affects fewer than 5 persons per 10,000 people $(1$ per 2,000$)$ and, in the USA - no more than 1 person per 1,250 people, which is slightly more frequent. Thus, it is estimated that there are around $350,000,000$ people suffering from rare diseases in the world. Around $80 \%$ of rare diseases have a genetic origin. Researchers also indicate that they mainly affect children up to 5 years of age (over $75 \%$ of patients). At the same time, it should be emphasised that only in the case of $3 \%$ of all diseases, pharmacological treatment is possible (Table 2) [Schieppati et al., 2008; Richter et al., 2015; Auvin et al., 2018]. 
Table 2. Rare diseases - statistics

\begin{tabular}{|c|c|c|c|}
\hline $\begin{array}{l}\text { The number } \\
\text { of classified rare } \\
\text { diseases }\end{array}$ & $7,000-8,000$ & & \\
\hline \multirow[b]{2}{*}{$\begin{array}{l}\text { Frequency } \\
\text { of occurrence }\end{array}$} & In the world & European Union & USA \\
\hline & $\begin{array}{l}350,000,000 \\
\text { people }\end{array}$ & \begin{tabular}{|c|}
$27,000-36,000$ people \\
e.g. in Poland $2.5-3,000,000$
\end{tabular} & $25,000,000-30,000,000$ people \\
\hline \multirow[t]{2}{*}{ Factors } & Genetic & $\begin{array}{l}\text { Other (e.g. tissue damage, } \\
\text { infection, teratogenic } \\
\text { effects of certain } \\
\text { substances) }\end{array}$ & \\
\hline & $80 \%$ & $20 \%$ & \\
\hline \multirow{2}{*}{ Patient's age } & Children & Adults & \\
\hline & $>75 \%$ & $<25 \%$ & \\
\hline \multirow[t]{2}{*}{ Mortality rate } & $\begin{array}{c}\text { Before } 5 \text { years } \\
\text { of age }\end{array}$ & Before 15 years of age & Adults \\
\hline & $30 \%$ & $40-45 \%$ & $10-25 \%$ \\
\hline \multirow{2}{*}{$\begin{array}{l}\text { Pharmacothe- } \\
\text { rapy }\end{array}$} & Accessibility & No treatment available & \\
\hline & $\begin{array}{c}\text { For } 3 \% \\
\text { of diseases }\end{array}$ & Ca. $97 \%$ & \\
\hline
\end{tabular}

Source: Schieppati et al., 2008; Richter et al., 2015; Auvin et al., 2018.

Approximately 7,000-8,000 rare diseases have been identified and described. They include Dandy-Walker syndrome and mucopolysaccharidosis type II (Hunter syndrome). There are no statistical data available concerning the number of children globally who have been diagnosed with both of these rare diseases.

Dandy-Walker syndrome (DWS) is a congenital malformation of the cerebellum and it involves cerebellar hypoplasia or agenesis, enlargement of the fourth ventricle with cyst formation in the posterior cranial fossa and elevated position of the cerebellar tentorium [Al-Turkistani, 2014]. According to clinical research, the DWS may be an isolated condition or it may coexist with other developmental disorders of the nervous system, urinary tract, skeletal system, heart and splanchnocranium [Golec, 2020]. It is reported that children diagnosed with this syndrome very frequently have motor dysfunctions and various degrees of intellectual disabilities. Very frequently, prognosis for proper intellectual development is poor [Kumar, Kumar Jain, Kumar Chhabra, 2001; Haddadi, Zare, Asadian, 2018].

Mucopolysaccharidosis type II (MPS II), also referred to as Hunter syndrome, was described in 1917 for the first time. It is a congenital metabolic defect triggered by acid mucopolysaccharide (Ggycosaminoglycan) metabolism disorders. The disease involves iduronate 2-sulfatase deficiency, causing the accumulation of dermatan sulfate and heparan sulfate, which leads to their excessive excretion in urine. Hunter syndrome is a genetic disorder and its inheritance is recessive and associated with chromosome X [Pytrus et al., 2006]. It is manifested in a child by malformations of the splanchnocranium and height, joints, skeletal system and heart disorders (Table 3). The intensity of the symptoms may 
be variable and every child develops in a different way. Most often, parents notice that the health condition of their son or daughter gradually deteriorates. A child is frequently diagnosed with hearing loss between the age of 2 and 3 years. Between the ages of 2 and 5 years, the intellectual and neurological development gradually stops and deteriorates. Children are also hyperactive and spastic and they gradually stop to grow between the ages of 2 and 6 years. Later, a child develops neurological disorders that may be acute including cardiological complications. Because of, among other things, a too large tongue, a distorted throat, a short and thick neck and gradual distortion and prostration of the trachea - causing obstruction of the respiratory tract - children die before they turn 15 [Pytrus et al., 2006; Martin et al., 2008; Wraith et al. 2008].

\section{Procedure}

The current research was qualitative rather than quantitative in nature, as there have been very few children diagnosed with two rare genetic and degenerative diseases.

\section{Method}

The method used was the individual case study using participant observation, indepth open interview with parents and analysis of the boy's (Adam) records from the years 2016 to 2020 . The following tools were used:

- Core Deficit Assessment Sheet [Nason, 2014]. The questionnaire consists of the following elements:

- Sensory deficits,

- Cognitive deficits,

- Emotional deficits,

- Social/communication deficits,

- Medical/psychiatric.

- Individual Communication Skill Sheet developed by Nowak and KobylackaSikora [2017]. This individual communication competence sheet examines a person's communication skills in 5 different areas - pre-verbal, verbal, interpersonal, intrapsychic and creative expression. Each area is assessed separately on a scale of $1-5$, where:

- Never discloses competences (0\%),

- Discloses competences only with help of a teacher/therapist/parent (25\%),

- Discloses competences rarely with appropriate support, guidance or control of the other person, sometimes independently $(50 \%)$,

- Discloses competences often (75\%),

- Discloses competences always (100\%).

- Functional Communication Parent Questionnaire developed by Wilson and Gildersleeve-Neumann [2014]. This questionnaire is designed to explore child's 
language use. It consists of the following sections: Names, Activities, Places, Requests and Needs, Emotions and Feelings, Toys and Materials, Food and Drink, Household Items and Places, Clothing, Question Words, Yes and No Responses, Social, Other words.

The above mentioned tools were used to write a case study of Adam's current functioning and his communication assessment.

The research began in 2016 and ended in 2020. The research covered, among other things, the rehabilitation programme that Adam attended, individual conversations with his parents and observation of activities, including therapeutic activities that he attended. Because the research lasted for four years, it was possible to observe the changes that took place in Adam's functioning and even in the quality of his life. They showed the progression of the disease and stages of deterioration of the milestones that he had previously achieved. Importantly, the observations focused on the gradual regression of speech. During the four years, speech regression and the development of complex communication needs were observed.

The main research question that was formulated was: What are the complex communication needs of a child diagnosed with Dandy-Walker syndrome and Hunter syndrome?

The following detailed questions were also formulated:

- What are the complex communication needs of a child with DWS and MPS II in the area of me as a person?

- What are the complex communication needs of a child with DWS and MPS II in the areas of education and therapy?

- What are the complex communication needs of a child with DWS and MPS II in the area of medical care?

\section{The research subject - Speech Development Description of the child}

The author met Adam when he was 8 years old and followed him until he was 12 .

\section{Pregnancy and delivery}

Adam was born in 2008 through a Caesarean section given the weight of the child. Based on ultrasonography (USG) examinations, the physician estimated that Adam would weigh 4,600 grams, but his actual weight on the day of delivery was 4,720 grams. Adam scored 10 in the Apgar scale. On the second day of his life, he had physiological jaundice. He was discharged home in a very good condition. A screening test revealed that the child had a hearing impairment. 


\section{Infancy}

At the age of 3 months, he was diagnosed with a hearing loss of $60 \mathrm{~dB}$ in the left ear and $70 \mathrm{~dB}$ in the right ear. He was prescribed bilateral hearing aids at the age of 4 months. Adam started cooing at the age of 3 months and babbling at the age of about 1-11 months. He said his first word "tata" when he was about 12 months old. Two months later (14 months of age), he could say "mama", "baba”, "dada". He often suffered from ear and upper respiratory tract infections and he was diagnosed with communicating hydrocephalus. At the same time, Adam was also diagnosed with Dandy-Walker syndrome having characteristic symptoms such as poor muscle tone, balance and coordination, problems with eye movement, mainly jerky eye movement, but no epileptic seizures were reported. Those syndromes were noted by parents and confirmed by neurologist.

Adam was included in an early development support programme due to hearing impairment from the first year of his life up until the end of his preschool education. By the time he was two years old, he attended therapy at a centre for children with hearing impairments.

\section{Preschool age}

Adam was diagnosed with mucopolysaccharidosis type II at the age of 5 years because his parents noticed his psychomotor development (he started stumbling, could walk only with adults' help) and speech regression (could communicate with a few phrases supported by gestures). That same year, he developed problems with swallowing. He did not salivate excessively and he could eat all kinds of food, provided it was blended and mixed with a sauce. By the age of 6 years, Adam suffered from chronic inner ear infections and bronchitis. He was also diagnosed with moderate intellectual disabilities.

\section{Early school age (existing condition)}

At this stage, Adam was diagnosed with a major intellectual and motor disability (he stopped walking independently when he was at the age of 8 , which is the time when the author met him). Adam stopped using verbal speech when he was 6 years so, when the author met him he could not communicate with words. However, receptively, he could select specific animals or colours by using eye movement when requested to do so. He could differentiate colours like red, yellow and blue, and digits: 1,2 and 3 . When he was 12 he had to have a tracheostomy due to increasing respiratory failure. Shortly after, he was given a percutaneous endoscopic gastrostomy (PEG), because he often choked and suffered from aspiration pneumonia. 


\section{Evaluation of the orofacial area}

Adam's baby teeth grew when he was 11 months and they fell out when he was 7.7 years old. He still has a couple of baby teeth (4 and 5). Adam had noticeably reduced muscle tone of the articulators which was diagnosed when he was at the same age. His tongue was enlarged and showed symptoms of macroglossia (Picture no. 1). He had problems protruding and retracting his tongue due to the greater weight of his tongue and reduced muscle tone (at the same age too).
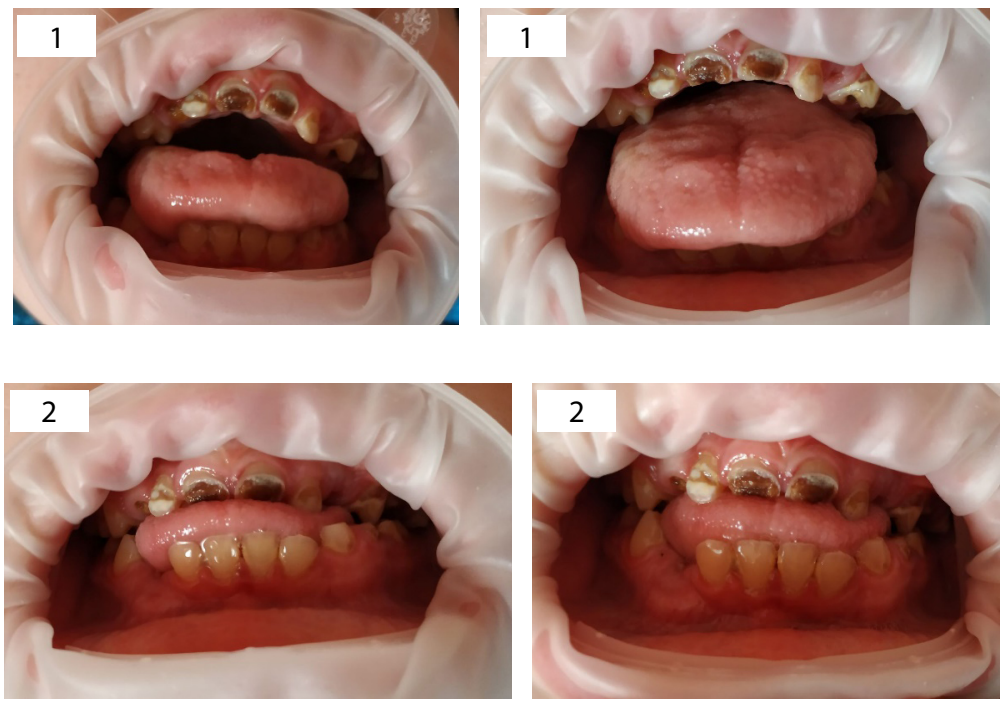

Picture no. 1. Tongue position in the examined child. Age 12: 1. Open oral cavity. 2. Closed oral cavity Source: own collection; permission to reproduce pictures was obtained from parents.

In a relaxed position, the tongue fills the oral cavity between the two corners of the mouth, which makes breathing difficult (Picture no. 2), hence a need for a tracheostomy tube when he was 12 years old.

Currently, at the age of 12 , Adam keeps his mouth open all the time and he salivates. He has dysphagia-related disorders such as impeded swallowing of food pieces or liquids, heartburn, coughing, often choking. His sublingual frenulum and palate are normal and his bite is open. 


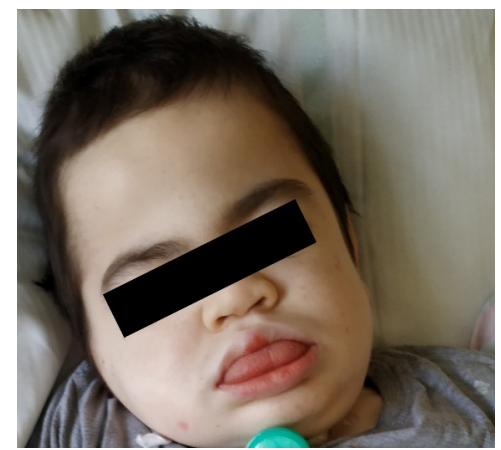

Picture no. 2. The tongue in a relaxed position. Age 12

Source: own collection; permission to reproduce pictures was obtained from parents.

\section{Communication assessment}

Currently, Adam does not talk. He is introduced to alternative communication such as PECS (Picture Exchange Communication System) [Frost, 2002]. Adam is learning to identify single pictures of family members (mother, sister) and favourite toys. Adam expresses sensations of his own body in a specific way like a crying face to let others he feels pain. He reacts to selected individual external stimuli like turning his head in the direction of his mother's voice and he relaxes when she touches him. He experiences states associated with satisfaction or deprivation of his basic needs (hungerfullness), when he is hungry, he puts his hand in his mother's mouth.

Adam reacts with different movements depending on the external signals, for example he smiles when he sees his mother or follows the people near him with his eyes. He responds to voice by actively looking for its source. He establishes eye contact but maintains it for a short while only. The behaviours observed when in contact with his environment includes reacting to the sound of his name; reacting to simple verbal messages concerning daily, repetitive rituals associated with washing, bathing, going out or feeding; signalling his needs associated with the daily rituals, for example, he points to a sponge when he wants to take a bath; initiating contacts with other people through gestures and touch, but this is limited to the members of his family and, signalling his needs with certain gestures and motions, for example, he tenses up when he has problems defecating.

Adam understands the meanings of certain words, such as "mum", "dad" and "sister" (at earlier stages he could only spell those words). When he is asked about his mother, he looks at her, but he does not call her. He looks at the person talking to him. He also remembers the names of animals and can point to them (with his eyes) when prompted verbally. 


\section{Results}

The results of this research indicates that Adam does not communicate verbally, which has affected his family and social roles when referencing to the definition of complex communication needs (CCN) presented in the theoretical section of this article. Currently, he does not go to school and his education and therapy are carried out at home only. He is excluded from many aspects of social life, for example, he does not go on school trips or attends school events (such as beginning of the school year or the teacher's day, etc.). He has problems communicating with various communication partners. Only his mother understands him, which means that her assistance is needed in contacts with any other person. The complex communication needs diagnosed Adam triggered the following needs in the area of "me as a person": to notice the effects of one's actions, to have a sense of being a member of a group, to engage in activities that will help develop one's own competencies and gain experience, and to be included in group activities (Table 1). These weaknesses are caused not only by his inability to communicate verbally, but also by his deteriorating health condition, which limits his physical activity and prevents him from learning new things and at times from going out as, sometimes, he is isolated from other people because of the flu. The research suggests that all of the above mentioned needs exist in the home and social environment area.

When considering his education, it was determined that there is no need for a teaching assistant/aide who would know alternative methods of communication and could adapt the classroom to multimodal communication and train other persons. Adam has an individualised education plan anyways, which means that if he does not go to school he does not need support in that environment. In the case of a face-to-face individualised education plan, teachers must be trained in alternative communication, and so there is no need to engage a teacher assistant. There was no need to create a controlled space in any institution like a centre or a school, since therapy is conducted in takes place in Adam's home. Adam has all the above mentioned medical educational. To address Adam's multiple needs, he should have access to two resources: first, a broad range of Information and Communication Technologies (ICT) tools that are important for teenagers and may constitute a basis for both education and therapy (exchange of information, pictures, films, etc.) and, second, a support group to provide encouragement for him and his family.

The first resource is not needed or useful because Adam has been diagnosed with major intellectual disability which limits his opportunities to use social media. Creating a peer support group for a child like Adam, is not possible because there are no data available on the number of children diagnosed with the same two rare diseases or about the physical and cognitive condition of such children. Another reason for the lack of this need is Adam's limited ability to be among peers including healthy peers. This is not only due to his communication disorders but also his significant diagnosed cognitive disorders. 


\section{Discussion}

Scientific publications that describe speech and communication disorders in children with Dandy-Walker syndrome and mucopolysaccharidosis type II usually present research embedded in qualitative strategy. This is because those diseases are rare and few children are diagnosed with them. Meanwhile, there are few medical publications concerning individuals diagnosed with both diseases. Children with Dandy-Walker syndrome are most typically diagnosed with dysarthric speech disorders (slurred speech) [Golec, 2020]. In the case of Hunter syndrome, speech development is noticeably delayed. Some children never learn to say full sentences. If an individual does not manifest any cognitive disorders, acquisition of linguistic skills is also hindered [Amartino, 2015]. Alpern notes that even though there is no uniform pattern of speech and communication disorders in children with Hunter syndrome, all of them manifest structural changes in the speech mechanism. Their articulatory and linguistic skills gradually deteriorate, which is associated, among other things, with gradual hearing loss, too large tongue or inflammation of the temporomandibular joints [Alpern, 1992].

Adam was diagnosed with both DWS and MPS II. He cooed and babbled, and at the age of 12-14 months he could say words like "tata", "baba", "dada". He never said simple or complex sentences. In subsequent years, he communicated using some vocalisation (murmuring). Currently, Adam does not talk or makes any sounds. This confirms Alpern's thesis of a non-uniform pattern of speech and communication Picture Exchange Communication System disorders in children with MPS II. Because of his inability to use language and the limited ability to communicate information, Adam was diagnosed with complex communication needs that affect, among other things, the quality of his life.

These needs concern himself and his family, and have ramifications toward social, educational, therapeutic and medical environments. When analysing the needs associated with Adam's CCN, it is also possible to suggest certain methods to meet those needs. They include, among other things:

- to stimulate and develop the child's activity so that it may trigger contacts with others, for example designing activities based on elements of cooperation which have a programmed button that states "I want to play a game with you";

- to support and manage activity in such a way that it stimulates communication, for example playing a picture matching game with adult's support;

- to use aided communication methods during activities, such as PECS or eyetracking;

- to develop the child's vocabulary for the activities that are most pertinent to Adam, his meals, his hygiene, a person he may want to see, etc.

- to teach the child to express his emotions using AAC communication;

- to include the child in family events with the parent's limited role of an interpreter and constant presence of the child's assistant; 
- to motivate the child to engage in communication;

- to consult the solutions used with the child's carers;

- to develop a strategy of corrective measures (concerning, for example, public space design);

- to create communication situations that make it easier to learn to communicate.

At the same time, it should be noted that, when describing the complex communication needs of a child diagnosed with two rare diseases, it is hard to comment on (discuss) the studies of other researchers. This is due to, among other things, two reasons. The first reason is a limited number of studies involving such cases and the second, as has already been mentioned, is the fact that speech and communication disorders in children with RD do not have a uniform pattern.

\section{Acknowledgments}

I would like to thank Adam's parents for allowing me to observe their child for four years and the Association for Mucopolysaccharidosis and Rare Diseases for enabling me to attend a rehabilitation programme together with Adam and his parents.

\section{References}

Al-Turkistani H.K., 2014, Dandy-Walker syndrome, "Journal of Taibah University Medical Sciences", vol. 9(3), pp. 209-212.

Alpern C., 1992, Hunter's Syndrome and Its Management in a Public School Setting, "Language, Speech, and Hearing Services in Schools", vol. 23, pp. 102-106.

Amartino H., 2015, Hunter Syndrome (Mucopolysaccharidosis II) - The Signs and Symptoms a Neurologist Needs to Know, "European Neurological Review", vol. 10(1), pp. 90-94.

Auvin S., Irwin J., Abi-Aad P., Battersby A., 2018, The Problem of Rarity: Estimation of Prevalence in Rare Disease, "Value in Health", vol. 21(5), pp. 501-507.

Department of Communities, Disability Services and Seniors, 2018, Complex communication needs, Brisbane: The State of Queensland.

Frost L., 2002, The Picture Exchange Communication System, "Neurophysiology and Neurogenic Speech and Language Disorders", vol. 12(2), pp. 13-15.

Golec W., 2020, Zespół Dandy'ego i Walkera, [in:] A. Dobrzańska, Ł. Obrycki, P. Socha (eds.), Choroby rzadkie. Standardy medyczne, Warszawa: Media-Press, pp. 589-590.

Grycman M., 2014, Porozumiewanie się z dziećmi ze złożonymi zaburzeniami komunikacji. Poradnik nie tylko dla rodziców, Kwidzyn: Stowarzyszenie Rehabilitacyjne Centrum Rozwoju Porozumiewania się.

Haddadi K., Zare A., Asadian L., 2018, Dandy-Walker Syndrome: A Review of New Diagnosis and Management in Children, "Journal of Pediatrics Review", vol. 6(2), pp. 47-52.

Hourcade J.P., Garzotto F., Rozga A., Tentori M., Markopoulos P., Pares N., Good J., Pain H., Alper M., 2014, Supporting Children with Complex Communication Needs, One of a CHInd, Toronto.

Johnston S.S., Blue Ch., Gevarter C., Ivy S., Stegenga S., 2020, Opportunity Barriers and Promising Practices for Supporting Individuals with Complex Communication Needs, "Current Developmental Disorders Reports", vol. 7, pp. 100-108. 
Kumar R., Kumar Jain M., Kumar Chhabra D., 2001, Dandy-Walker syndrome: different modalities of treatment and outcome in 42 cases, "Child's Nervous System", vol. 17, pp. 348-352.

Martin R., Beck M., Eng Ch., Giugliani R., Harmatz P., Munoz V., Muenzer J., 2008, Recognition and Diagnosis of Mucopolysaccharidosis II (Hunter Syndrome), "Pediatrics", vol. 121(2), pp. e377-e386.

McNaughton D., Bryen D., Blackstone S., Williams M., Kennedy P., 2012, Young Adults with Complex Communication Needs: Research and Development in AAC for A "Diverse" Population, "Assistive Technology", vol. 24(1), pp. 45-53.

Nason B., 2014, The Autism Discussion Page on the Core Challenges of Autism, London: Jessica Kingsley Publishers.

Nowak A., Kobylacka-Sikora K., 2017, Indywidualny Arkusz Kompetencji Komunikacyjnych. Komunikacja kluczem do integracji, Unia Europejska: Europejski Fundusz Społeczny.

Parliament of Victoria Family and Community Development Committee, 2016, Inquiry into abuse in disability services. Final Report, Australia, Victoria, https://www.parliament.vic.gov.au/fi le_uploads/FCDC_-_Inquiry_into_abuse_in_disability_services_HtW37zgf.pdf (accessed: 22.10.2020).

Pickl G., 2008, Children with complex communication needs. The parents' perspective, Stockholm: Stockholm University.

Pytrus T., Iwańczak B., Wawro J., Czartoryska B., Iwańczak F., 2006, Mucopolysaccharidosis II (Hunter Syndrome) - Case Report, "Advances in Clinical and Experimental Medicine", vol. 15(2), pp. 399-403.

Richter T., Nestler-Parr S., Babela R., Khan Z.M., Tesoro T., Molsen E., Hughes D.A., 2015, Rare Disease Terminology and Definitions - A Systematic Global Review: Report of the ISPOR Rare Disease Special Interest Group, "Value in Health", vol. 18(6), pp. 906-914.

Schieppati A., Henter J.I., Daina E., Aperia A., 2008, Why rare diseases are an important medical and social issue, "Essay Focus", vol. 371(9629), pp. 2039-2041.

Sigafoos J., Gevarter C., 2019, Introduction to he Special Issue: Communication Intervention for Individuals with Complex Communication Needs, "Behavior Modification", vol. 43(6), pp. 767-773.

Wilson A., Gildersleeve-Neumann C.E., 2014, Functional Communication Parent Questionnaire, Unpublished instrument, Portland: Portland State University.

Wraith J.E., Scarpa M., Beck M., Bodamer O.A., De Meirleir L., Guffon N., Lund A.M., Malm G., Van der Ploeg A.T., Zeman J., 2008, Mucopolysaccharidosis type II (Hunter syndrome): a clinical review and recommendations for treatment in the era of enzyme replacement therapy, "European Journal of Pediatrics", vol. 167, pp. 267-277.

\begin{tabular}{|c|c|}
\hline & $\begin{array}{l}\text { (c) by the author, licensee Łódź University - Łódź University Press, Łódź, Poland. } \\
\text { This article is an open access article distributed under the terms and conditions } \\
\text { of the Creative Commons Attribution license CC-BY-NC-ND } 4.0 \\
\text { (https://creativecommons.org/licenses/by-nc-nd/4.0/) }\end{array}$ \\
\hline & Received: 6.07.2021. Accepted: 24.10.2021. \\
\hline
\end{tabular}

